\title{
Have wet meadow restoration projects in the Southwestern U.S. been effective in restoring geomorphology, hydrology, soils, and plant species composition?
}

Karissa M Ramstead ${ }^{1}$, James A Allen ${ }^{1 *}$ and Abraham E Springer ${ }^{2}$

\begin{abstract}
Background: Wet meadows occur in numerous locations throughout the American Southwest, but in many cases have become heavily degraded. Among other things they have frequently been overgrazed and have had roads built through them, which have affected the hydrology of these wetland ecosystems. Because of the important hydrologic and ecological functions they are believed to perform, there is currently significant interest in wet meadow restoration. Several restoration projects have been completed recently or are underway in the region, sometimes at considerable expense and with minimal monitoring. The objective of this review was to evaluate the effects of wet meadow restoration projects in the southwestern United States on geomorphology, hydrology, soils and plant species composition. A secondary objective was to determine the effects of wet meadow restoration projects on wildlife.
\end{abstract}

Methods: Electronic databases, internet search engines, websites and personal contacts were used to find articles of relevance to this review. Articles were filtered by title, abstract and full text. Summary information for each of the articles remaining after the filtering process was compiled and used to assess the quality of the evidence presented using two different approaches.

Results: Our searches yielded 48 articles, of which 25 were published in peer-reviewed journals, 14 were monitoring or project reports, and 9 were published in conference proceedings or are unpublished theses or manuscripts.

A total of 26 operational-scale restoration projects were identified. A wide range of restoration techniques were employed, ranging from small-scale manipulations of stream channels (e.g., riffle structures) to large scale pondand-plug projects. Other common restoration techniques included fencing to exclude livestock (and sometimes also native ungulates), other forms of grazing management, seeding, and transplanting seedlings.

Most of the articles reported that restoration was fully or partially effective, at least in the short-term. However, the relative lack of high quality quantitative data, and especially data extending more than two years after project implementation, greatly limits our ability to determine how effective restoration has truly been in practice.

\footnotetext{
* Correspondence: James.Allen@nau.edu

'School of Forestry, Northern Arizona University, P.O. Box 15018, Flagstaff, AZ 86011, USA

Full list of author information is available at the end of the article
} 
(Continued from previous page)

Conclusions: While caution is warranted due to data quality limitations, progress has been made over the past 20 years in wet meadow restoration. In particular, important contributions have been made in restoring the highly degraded wet meadow systems that are characterized by deep, wide and relatively straight gullies. There is evidence, for example, that the pond-and-plug approach is an effective technique for restoring many aspects of these systems, albeit at the cost of creating new features (ponds) that are not necessarily natural features of wet meadows.

There is a need to allocate additional effort to project documentation, including better-designed and longer-lasting monitoring programs. One approach that might help is for practitioners to work with scientists from government agencies, local universities and colleges, and other organizations. When this type of collaboration has happened in the past it appears to have been effective. Many important lessons could have been learned, and mistakes avoided, if more effort had been put into documenting both successes and failures of past projects.

Keywords: Systematic review, Wetland, Riparian, Biodiversity

\section{Background Introduction}

High elevation streamside and groundwater-fed meadows occur in numerous locations throughout the American Southwest. They are referred to by a variety of names, such as riparian meadows, montane meadows, subalpine meadows, sedge meadows, or wet meadows. For the remainder of this review the term wet meadow will be used.

Where wet meadows have not been excessively altered, sedges (Carex spp.), rushes (Juncus spp.), spikerushes (Eleocharis spp.) and obligate or facultative wetland grasses (e.g., Deschampsia spp. and Calamagrostis spp.) are often the dominant species [1-4]. Willow (Salix spp.) and alder (Alnus spp.) species may also occur in or adjacent to these meadows [4-7].

Wet meadows in the American Southwest frequently occur along elevation gradients that include a stream or other water body at the lower end. The upland side may contain a vegetation community gradient including some of these types: mesic meadows, dry meadows, sagebrush (Artemesia spp.), pine (Pinus spp.) dominated forest, or mixed conifer forest. These elevation and vegetation gradients are closely associated with differences in flooding, depth to water table/soil moisture content, and other soil characteristics. Wet meadows typically occur on sites with water table levels near or slightly above the ground surface throughout the spring and early summer [8-11].

\section{Distribution of wet meadows in the American Southwest}

The extent of wet meadows in the American Southwest which we define as the states of Arizona, California, Colorado, Nevada, New Mexico and Utah - is not well documented. When considered within the context of the entire southwestern landscape, we know that wet meadows are relatively rare. Less than $1 \%$ of the landscape in the region is characterized as wetlands [12], and wet meadows are just one of several wetland types that occur. Within certain subregions, however, wet meadows can be locally common. Approximately 133,000 ha of meadows are reported to occur in the Sierra Nevada Mountains of California [13]. That acreage is distributed among more than 10,000 individual meadows [13]; however, it is not clear what proportion of those meadows would be classified as wet meadows. Patton and Judd [1] reported that approximately 17,700 ha of wet and transitional (moist) meadows occur on national forests in Arizona and New Mexico, together accounting for $0.2 \%$ of the total area.

\section{Ecological roles of wet meadows}

Wet meadows are key habitats for many species. Elk (Cervus elaphus) and other large ungulates, for example, have been shown to make extensive use of wet meadows as foraging sites $[1,14]$. Small mammals that use wet meadows include meadow voles (Microtus spp.), pocket gophers (Thomomys spp.), field mice (Peromyscus spp.), shrews (Sorex spp.), and American minks (Mustela vison). In the Sierra Nevada Mountains, 82 terrestrial vertebrate species are dependent on riparian and meadow habitats [13].

In addition to the common wildlife species that are dependent on wet meadows, several threatened, endangered and sensitive species also occur. For example, threatened, endangered and sensitive species in the Sierra Nevada that use wet meadows for at least a portion of their life cycle requirements include the Yosemite toad (Bufo canoru), the mountain yellow-legged frog (Rana muscosa), the willow flycatcher (Empidonax traillii), and the great gray owl (Strix nebulosa;13). In east central Arizona populations of Apache trout (Onocorhynchus gilae var. apache) endemic to high elevation streams have dwindled due to habitat degradation, resulting in its listing as an endangered species [15].

Although generally less well-documented than the roles described above, wet meadows also perform other 
important ecosystem functions that are commonly attributed to wetlands, such as water-quality improvement, attenuation of peak flows, water storage, and carbon sequestration $[13,16,17]$.

\section{Alterations of wet meadow ecosystems}

Wet meadows are subject to a variety of natural disturbances and are also one of the ecosystem types in the American Southwest that has been most altered by humans. Among other things, they have been used extensively for livestock grazing, are the sites of many small dams and stock tanks, have had roads built through or adjacent to them, and have been impacted by wild ungulate grazing, invasive species and wildfires in the surrounding uplands. These types of alterations have in turn had important impacts on the hydrology of wet meadows, most notably by lowering of their water tables due to stream channel incision, surface water diversions, or groundwater withdrawal [16,18-20]. In the Sierra Nevada Mountains, an estimated 52,630 to 80,970 ha of wet meadows have been impacted by these types of disturbances over the past 150 years [13]. Impacts include severe erosion, soil desiccation, shrub and tree encroachment, and changes in plant and animal species composition and diversity $[13,21,22]$.

\section{Objectives}

The primary objective of this review is to address the question "Have wet meadow restoration projects in the southwestern United States been effective in restoring geomorphology, hydrology, soils, and plant species composition?" A secondary objective is to address the question "Have wildlife species increased in diversity and/or abundance following wet meadow restoration?"

\section{Methods}

\section{Question formulation}

The subject of wet meadow restoration was proposed by the reviewers primarily because of our observation that an increasing number of wet meadow restoration projects have been implemented in the region in recent years. Based on our discussions with resource managers involved in wet meadow restoration projects, it was apparent to us that the outcomes of these projects have been mixed. Furthermore, relatively little information on the successes and failures of wet meadow restoration projects seemed to be published or otherwise shared among managers across the region. We conducted a survey of managers [23] that helped refine our research questions and also provided evidence that many more wet meadow restoration projects are likely to be implemented over the next decade.

\section{Search strategy}

Electronic databases available through Northern Arizona University's Cline Library were the primary source. The following databases were used:

- Academic Search Premier

- BioOne

- CSA

- Forest Science Database (Ovid)

- JSTOR

- Northern Arizona University 360

- ProQuest

- Wilson OmniFile

Additional sources of information included:

- Google Scholar (a search engine)

- Government and university websites and libraries (e.g., USDA Forest Service's TreeSearch)

- Unpublished reports (e.g., project monitoring reports) were sought directly from individuals and organizations responsible for restoration projects.

Searches included the following English language search terms:

("denotes = wet meadow, riparian meadow, sedge meadow, or montane meadow)

1. Wet Meadow* AND Restoration

2. Wet Meadow" AND Hydrology

3. Wet Meadow" AND Grazing

4. Wet Meadow* AND Erosion

5. Wet Meadow* AND Sedimentation

6. Wet Meadow" AND Channel

7. Wet Meadow* AND Biodiversity

8. Wet Meadow* AND Carex

9. Wet Meadow* AND Juncus

The majority of the database searches were conducted between July and October 2009, although additional searches were made as late as October 2011. The latter searches relied primarily on other sources than databases, including Google Scholar and organizational websites. They were also aided by personal contacts with restoration practitioners that had developed over the course of the review. Google Scholar was used to search for new articles published after the date of the database searches. Several searches were made using the custom date range feature; only the first ten pages of search results were examined.

\section{Study inclusion criteria}

Inclusion criteria were broken down into the four categories described below. 


\section{Relevant subject(s) and geographic area}

- Herbaceous and mixed herbaceous/scrub-shrub dominated riparian ecosystems that are clearly wetlands (e.g., dominated by obligate or facultative wetland species in genera such as Carex spp., Juncus spp., Salix spp., and Alnus spp.); meadows adjacent to these wetlands that are more typically characterized as mesic and that often have a diverse flora characterized by facultative or facultative wetland species, including a greater number of grass and forb species than typically found in wet meadows. Only studies conducted in Arizona, California, Colorado, Nevada, New Mexico or Utah were used for data extraction, although other articles were retained through the full text filtering stage for possible use in the assessment of study limitations and future research needs.

\section{Types of intervention}

- Geomorphological and/or soil restoration techniques (e.g., pond-and-plug, channel relocation, site re-contouring, topsoil placement or removal).

- Hydrologic restoration techniques (e.g., check dams, artificial riffle formations). However, articles that focused entirely on stream or fisheries habitat restoration, even if the stream flowed through a wet meadow, were not included.

- Vegetation restoration techniques (e.g., seeding, planting, herbivore exclusion).

- Modifications of adjacent areas (e.g., thinning of adjacent upland forests).

\section{Types of study}

- All primary experimental and observational studies.

\section{Types of outcome}

- Geomorphological and soil outcomes such as channel stability, presence/movement of nick points, and development of redoximorphic soil properties.

- Hydrologic outcomes such as changes in water table levels and flooding depth, duration and/or timing.

- Vegetation outcomes such as species composition, percent cover and biomass, survival of planted material, and presence or absence of invasive species.

- Biodiversity outcomes such as change in species richness, evenness, or abundance due to restoration treatments or grazing management changes.

Using a progressive filtering approach, Karissa Ramstead first eliminated all articles that clearly did not meet our inclusion criteria based solely on their titles. She next read the abstracts (when available) of the remaining articles and eliminated those that upon closer inspection also did not meet the inclusion criteria. Finally, the articles remaining after the abstract filter were read in full to determine which were suitable for data extraction. All articles identified by Ramstead for potential inclusion were then reviewed by a second reviewer (James Allen).

\section{Study quality assessment}

After the articles were selected for review, Ramstead rated them using Pullin and Knight's Hierarchy of Quality of Evidence [24]. A Kappa test was then performed using 15 randomly selected articles to assess the two primary reviewers' (Allen and Ramstead) level of agreement about their quality. In addition to this rating approach, which is widely used in systematic reviews on conservation biology-related topics, we also developed the more specific assessment approach that is described in the Data synthesis and presentation section.

\section{Data extraction}

All articles that remained after full text filtering were summarized in a master spreadsheet (Additional file 1: Appendix A). Information extracted included study location, outcome (in terms of how it related to our primary and secondary questions), restoration intervention(s), research/monitoring methods used to assess the project, and results.

\section{Data synthesis and presentation}

Information on study location and on intervention(s) employed was used to examine overall patterns across the region in terms of where restoration has been done to date and what practices have been most commonly used. A two-part analysis was then done to assess the evidence of restoration effectiveness.

For the first part of the analysis of restoration effectiveness, we compiled a list of six characteristics of functional wet meadow ecosystems, which we also considered to be useful criteria for assessing the success of wet meadow restoration projects (Table 1). Our list was modified from a previous one developed for southwestern riparian ecosystems by Medina [16] and includes at least one characteristic that is directly related to each of the five outcomes addressed by our primary or secondary questions. The descriptions of each characteristic were modified from the previous list to be more specific to wet meadows and the new list was expanded to include the types of evidence that we considered to be useful for the assessment of each characteristic. Using the descriptions and types of evidence as guidelines, we then determined if each particular characteristic was addressed and, if so, whether there was sufficient 
Table 1 Characteristics of functional wet meadow ecosystems (modified from [16])

\begin{tabular}{|c|c|c|}
\hline Characteristic & Description & Assessment \\
\hline \multirow[t]{2}{*}{$\begin{array}{l}\text { Suitable Stream } \\
\text { Morphology }\end{array}$} & \multirow{2}{*}{$\begin{array}{l}\text { A low gradient stream with a low width:depth ratio }(<12) \\
\text { and medium to high sinuosity }(>1.2) \text {, except in meadows } \\
\text { believed to have no natural channel (e.g. [25]) }\end{array}$} & $\begin{array}{l}\text { Best evidence: Survey data on pre- and } \\
\text { post-project stream channel morphology }\end{array}$ \\
\hline & & $\begin{array}{l}\text { Other evidence: Photo points, high resolution } \\
\text { aerial photography, qualitative descriptions }\end{array}$ \\
\hline \multirow[t]{2}{*}{$\begin{array}{l}\text { Stable } \\
\text { Streambanks }\end{array}$} & \multirow{2}{*}{$\begin{array}{l}\text { Streambanks with the capacity to withstand repeated high } \\
\text { water/flooding events without significant loss of bank } \\
\text { material (except in meadows believed to have no natural } \\
\text { channel (e.g. [25]) }\end{array}$} & $\begin{array}{l}\text { Best evidence: Survey data on post-project stream } \\
\text { channel morphology following repeated hydrologic } \\
\text { events }\end{array}$ \\
\hline & & $\begin{array}{l}\text { Other evidence: Photo points taken after several seasons, } \\
\text { qualitative descriptions of the effects of hydrologic events }\end{array}$ \\
\hline \multirow[t]{2}{*}{$\begin{array}{l}\text { High Water } \\
\text { Table }\end{array}$} & \multirow{2}{*}{$\begin{array}{l}\text { High water tables are present within the meadow for long } \\
\text { enough periods to result in reduced soil conditions near } \\
\text { the soil surface (i.e. water table }<30 \mathrm{~cm} \text { from soil surface } \\
\text { for a period of at least } 14 \text { consecutive days during the } \\
\text { growing season) and that allows for the support of } \\
\text { native wetland plant species }\end{array}$} & $\begin{array}{l}\text { Best evidence: Data from water table wells and stream } \\
\text { hydrographs; redox potential measurements taken within } \\
\text { the top } 30 \mathrm{~cm} \text { of the soil column. }\end{array}$ \\
\hline & & $\begin{array}{l}\text { Other evidence: Visual observations of water levels, } \\
\text { evidence of flooding, and soil redoximorphic characteristics; } \\
\text { evidence of a transition to hydrophytic vegetation }\end{array}$ \\
\hline \multirow[t]{2}{*}{$\begin{array}{l}\text { Organic Matter } \\
\text { Assimilation }\end{array}$} & \multirow{2}{*}{$\begin{array}{l}\text { Characterized by a high percentage of organic matter } \\
\text { in diagnostic soil horizons and/or a high rate of organic } \\
\text { matter accumulation (the latter may be especially } \\
\text { important in newer restoration sites) }\end{array}$} & $\begin{array}{l}\text { Best evidence: Measurements of soil organic matter content, } \\
\text { with comparison to suitable reference sites }\end{array}$ \\
\hline & & $\begin{array}{l}\text { Other evidence: Descriptions of soil horizons, soil color } \\
\text { assessments using Munsell soil color charts }\end{array}$ \\
\hline \multirow[t]{2}{*}{$\begin{array}{l}\text { Perennial Native } \\
\text { Vegetation }\end{array}$} & \multirow{2}{*}{$\begin{array}{l}\text { Perennial native vegetation covers } \geq 75 \% \text { of the streambanks } \\
\text { and } \geq 50 \% \text { of the floodplain and is comprised } \\
\text { predominantly of native, perennial species, especially } \\
\text { wetland graminoid species with extensive and highly } \\
\text { fibrous root systems (e.g., Carex spp.) }\end{array}$} & $\begin{array}{l}\text { Best evidence: Quantitative data on species composition, } \\
\text { cover and biomass using accepted vegetation measurement } \\
\text { techniques and appropriate sample sizes }\end{array}$ \\
\hline & & $\begin{array}{l}\text { Other evidence: Quantitative data from small samples; photo } \\
\text { points; qualitative descriptions }\end{array}$ \\
\hline \multirow[t]{2}{*}{$\begin{array}{l}\text { Presence of } \\
\text { Native Fauna }\end{array}$} & \multirow{2}{*}{$\begin{array}{l}\text { The presence and relative abundance of both aquatic } \\
\text { and terrestrial organisms is similar to comparable } \\
\text { reference sites }\end{array}$} & $\begin{array}{l}\text { Best evidence: Quantitative data on target species using } \\
\text { accepted techniques and sampling intensities }\end{array}$ \\
\hline & & $\begin{array}{l}\text { Other evidence: Visual evidence of species presence and } \\
\text { abundance }\end{array}$ \\
\hline
\end{tabular}

evidence presented to determine if the project was successful in achieving the desired characteristic. For this analysis, we used the five-point rating system shown in Table 2 and assessed only those articles that presented data for the operational-scale restoration projects, as opposed to articles that presented data collected primarily for research purposes. While we believe that most wet meadow restoration practitioners would agree that these six characteristics are important, they represent our view of what constitutes successful restoration and weren't always listed as explicit goals in the articles we assessed.

The second part of our analysis of restoration effectiveness consists of a narrative that synthesizes the results of all the articles in relation to our primary and secondary questions, with separate subsections of the results being devoted to the effects of restoration on (1) geomorphology, (2) hydrology, (3) soils, (4) vegetation and (5) wildlife/biodiversity.

\section{Results}

\section{Review statistics}

More than 27,500 publications were identified through our initial searches (Additional file 2: Appendix B), the vast majority of which were eliminated during the title filtering stage. After full text review, we retained 40 articles (Table 3). In Additional file 3, we provide a list of 170 additional articles that we retained through the full

Table 2 Rating system used for assessing evidence for restoration effectiveness

\begin{tabular}{lcc}
\hline \multicolumn{1}{c}{ Assessment of evidence presented } & Rating \\
\hline Characteristic not mentioned & N/A \\
\hline Characteristic mentioned; evidence presented to demonstrate failure & 0 \\
\hline Characteristic mentioned; no evidence presented to demonstrate success & 2 \\
\hline Characteristic mentioned; insufficient evidence presented to demonstrate success & 3 \\
\hline Characteristic mentioned; sufficient evidence presented to demonstrate partial success & 4 \\
\hline "Characteristic" refers to those listed in Table 1; "mentioned" refers to whether or not the characteristic was listed as specific goal of the restoration project.
\end{tabular}


text review, but that we excluded from the data extraction phase for the reasons provided. We believe these articles may be a useful resource for those with an interest in wet meadow restoration outside of the American Southwest. As we continued to work on the review, we located an additional 8 articles that we included, bringing the total to 48 . All of these new articles were "grey literature" that we became aware of through Google Scholar searches or personal contacts.

\section{Study description}

The articles selected for inclusion in this review are diverse. Twenty-five of the included articles reported on research that was directly or indirectly related to wet meadow restoration and was published in peer-reviewed journals. Another 14 articles are better described as monitoring or project reports. The remaining 9 articles are mostly conference proceedings and unpublished theses or manuscripts.

Many articles only addressed one or two of our four main outcomes (i.e. effects on geomorphology, hydrology, soils, and vegetation). Geomorphology was addressed in 20 of the articles, hydrology in 18, soils in 8 , and vegetation in 38 . We found 13 articles that addressed our secondary question regarding the effects of restoration on wildlife/biodiversity.

Of the 48 articles selected for inclusion in this review, a total of 26 operational-scale restoration projects (as opposed to projects done strictly for research purposes and generally implemented at smaller scales) were identified. Of the 26 projects, 10 were in Arizona, 3 were in New Mexico, 12 were in California, and 1 was in Nevada (Figure 1).

At least 32 different types of restoration or research interventions were identified, with most being reported in only 1 or 2 articles (Figure 2, note some types of interventions are lumped into categories such as Other and "Greenhouse" Studies). The most common interventions were transplanting of vegetation, various forms of grazing management (including exclosures), and use of the pond-and-plug method for restoration of geomorphology and hydrology.

Because of the wide variation in study design, study quality, restoration/research interventions and the way that intervention effects were reported (which in many cases was primarily qualitative), we determined that the use of formal statistical meta-analysis techniques would not be practical. Two additional reasons why we opted not to conduct a meta-analysis include: (1) the relatively short-term nature of the studies, such that the true effects of restoration treatments had not yet been fully tested in many cases and (2) wide year-to-year variation in environmental conditions, especially related to precipitation and its effect on flooding and water table levels, that confounded treatment effects in otherwise well-designed studies e.g., [26,27].

\section{Study quality assessment}

The variation in types of study referred to in the previous section was reflected in their quality ratings (Figure 3). The Kappa analysis conducted by Ramstead and Allen showed 100\% agreement between the two reviewers based on the ratings initially assigned by Ramstead to 15 randomly selected articles (Cohen's Kappa statistic $=1.0$ ). However, we did experience difficulties deciding how to classify some articles, especially ones that were primarily about modelling studies and to a lesser degree some of the monitoring reports, that didn't seem to fit cleanly into the Pullin and Knight hierarchy.

\section{Evidence of effectiveness}

A summary of the evidence of restoration effectiveness is presented in Table 4 for the operational-scale restoration projects. Out of 162 individual ratings (27 studies x 6 characteristics), 56 (34.6\%) were rated "N/A." Evidence was presented more frequently for the effects of restoration on perennial vegetation, stream morphology, and streambank stability (i.e. for vegetation and geomorphology) than for the other three characteristics. The characteristic examined least frequently was organic matter assimilation, which was mentioned in just two of the articles, only one of which presented quantitative data.

None of the characteristics had an average rating above 3 - the amount of evidence needed to demonstrate partial success. Of greater importance than the average ratings, however, are the individual ratings of either 3 or 4 . These ratings indicate where restoration

Table 3 Articles included during filtering stages

\begin{tabular}{lc}
\hline \multicolumn{1}{c}{ Review stage } & Number of articles \\
\hline Publications captured from electronic databases (excluding duplicates) & $\sim 27,500$ \\
\hline Publications captured by other sources & 50 \\
\hline Publications remaining after title filter & $\sim 550$ \\
\hline Publications remaining after abstract filter & 210 \\
\hline Publications remaining after full text filter that were retained for data extraction & 40 \\
\hline
\end{tabular}




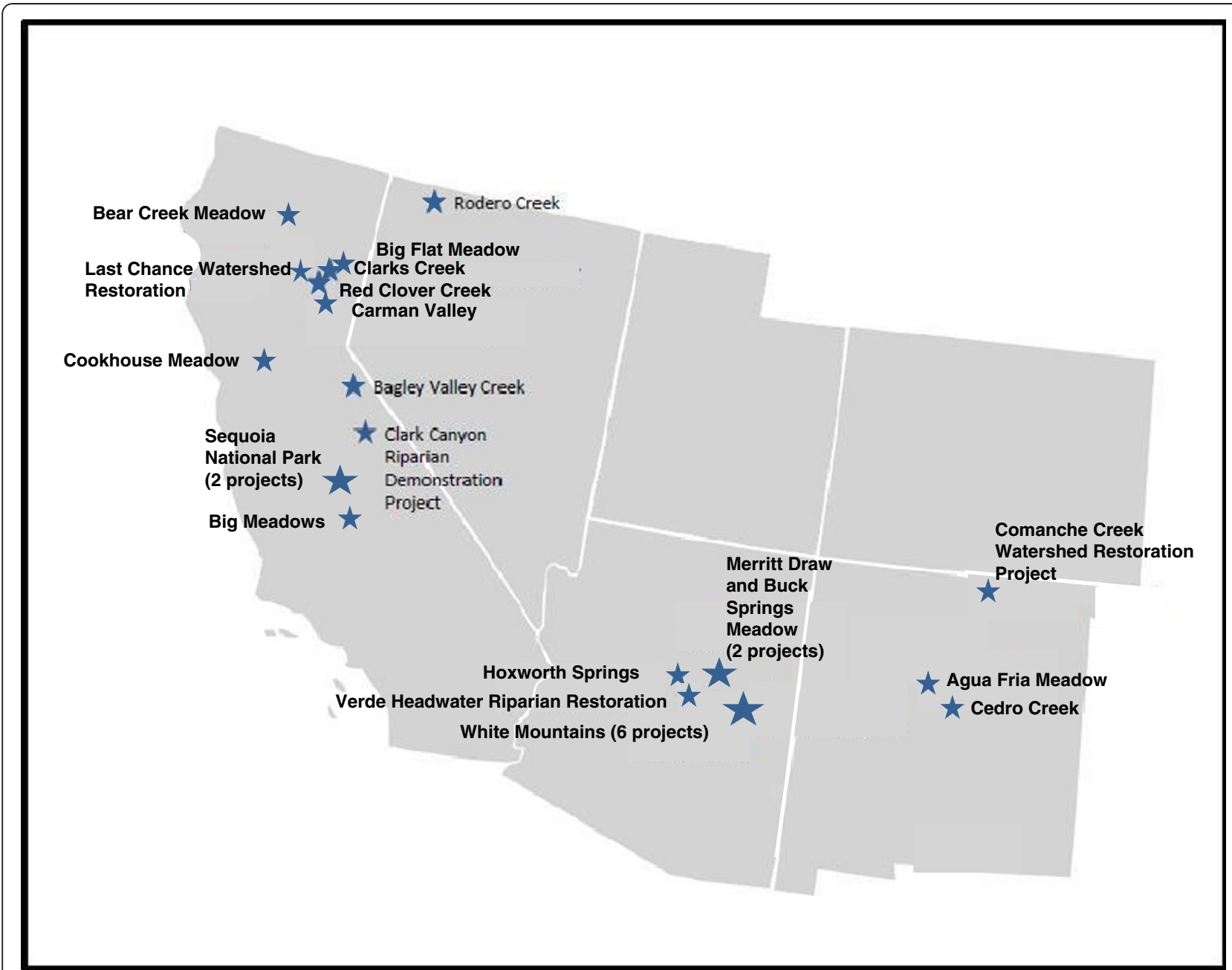

Figure 1 Approximate locations of the $\mathbf{2 6}$ operational-scale restoration projects included in this review. Because of their close proximity, some stars indicate more than one project.

techniques have been effective in improving specific wet meadow characteristics. Out of the total of 162 individual ratings in Table 4, there were 12 ratings of $4(7.4 \%$ of the total) and 51 ratings of 3 (31.5\% of the total). In the following subsections, we rely heavily on the evidence with ratings of 3 or 4 , along with supporting evidence from the smaller, research-scale studies not included in Table 4, to provide a synthesis of the evidence of restoration effectiveness.

\section{Geomorphology}

Restoration of project site geomorphology was of central importance in the majority of restoration projects we reviewed. In most cases, this involved measures to restore or recreate a stream channel with a gradient, sinuosity, width-to-depth and entrenchment ratios, and other characteristics that were similar to what existed in the meadow prior to stream incision or other alteration. Only in one case [25] did we find that the goal was to eliminate a channel from a meadow and to establish a sheet flow hydrologic regime.

The restoration practices employed varied depending on the pre-project condition of the stream channel. In meadows where the stream was not deeply incised, relatively simple and inexpensive practices such as using locally available rocks and gravel to construct riffle structures e.g., [38] were typically employed. Where streams were more deeply incised, approaches such as "re-channelization" (i.e., reconfiguring the existing channel or constructing a new one) have been used $[28,29,32]$.

In some of the most highly altered meadows, where the original shallow and meandering stream had been replaced by a deep, wide, and relatively straight gully, the pond-and-plug technique has been employed. This technique involves creating a series of earthen plugs in the gully by using fill material from within and adjacent to the gully (thereby creating alternating ponds and plugs). Streamflow is then diverted into either a remnant 


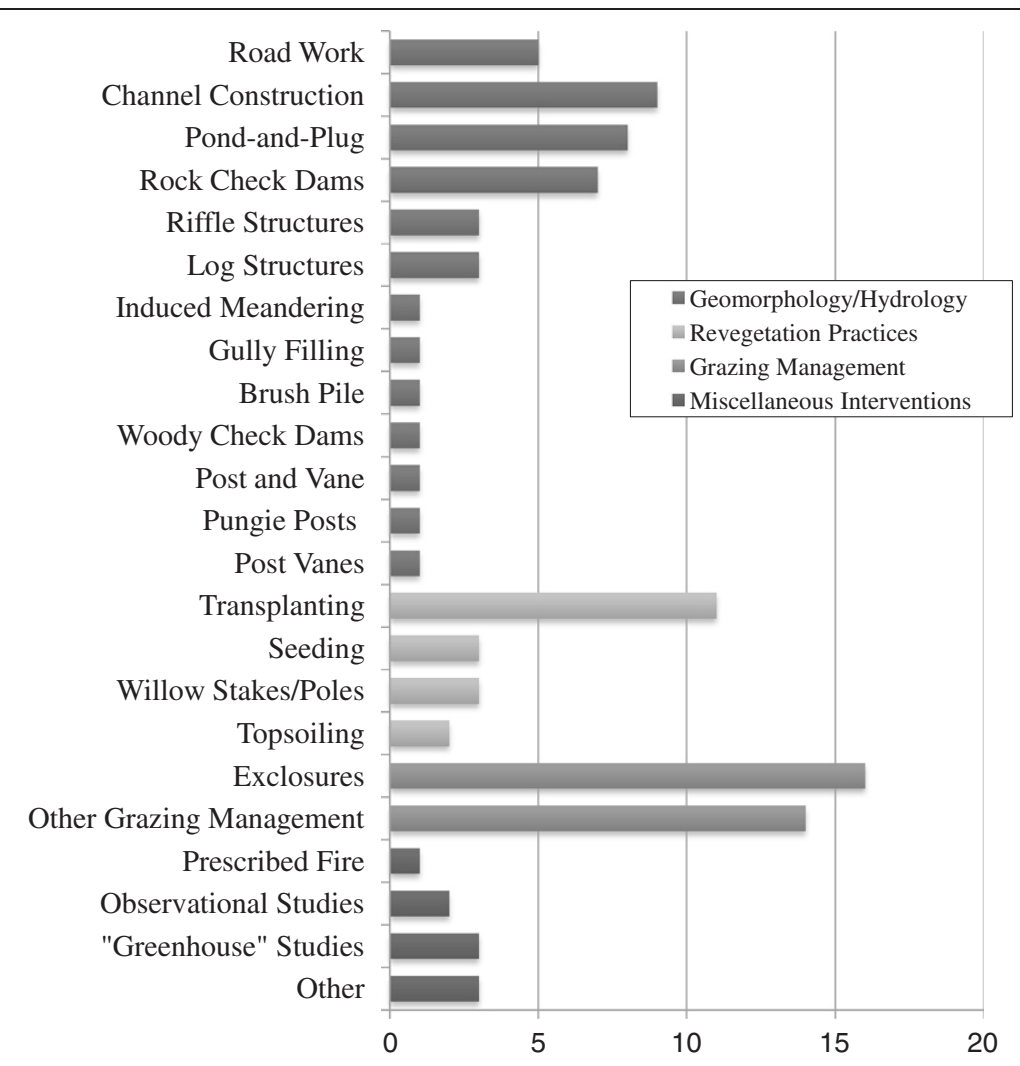

Figure 2 Types of restoration interventions (treatments) reported. The category "Greenhouse" Studies includes research projects that involved the manipulation of growing conditions such as light, temperature, or water table level in artificial environments.

stream channel or a newly created one on the original floodplain surface. This approach recreates part of the geomorphology of the meadow, but also results in a number of ponds that were not a feature of the original landscape. The pond-and-plug approach was first employed approximately 15 years ago and has been used with increasing frequency, particularly in the Sierra Nevada region of California [51].
The articles that we reviewed present a considerable amount of evidence that geomorphological restoration techniques can be effective. Pre- and post-project longitudinal profiles, stream and/or floodplain cross-sections, characterization of streambed particle size, and qualitative evidence (e.g., photo points) were the most frequently used types of evidence. These types of evidence, especially the stream profiles and cross-sections, can

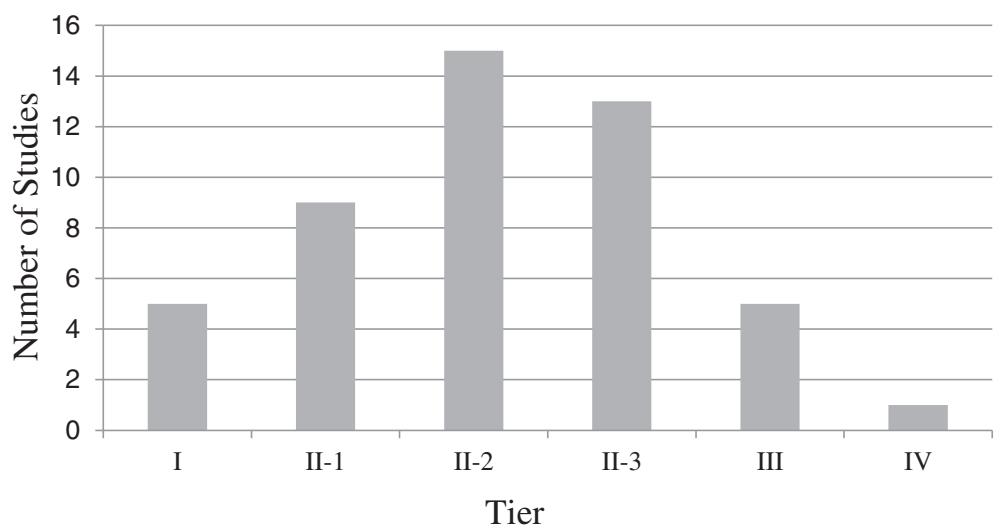

Figure 3 The number of articles by Pullin and Knight's [24 ] hierarchy of evidence category. 
Table 4 Evidence ratings of the success of wet meadow restoration projects

\begin{tabular}{|c|c|c|c|c|c|c|c|}
\hline \multirow[b]{2}{*}{ Article } & \multicolumn{7}{|c|}{ Characteristics of a functional wet meadow ecosystem } \\
\hline & $\begin{array}{c}\text { Suitable stream } \\
\text { morphology }\end{array}$ & $\begin{array}{c}\text { Stable } \\
\text { streambanks }\end{array}$ & $\begin{array}{l}\text { High water } \\
\text { table }\end{array}$ & $\begin{array}{c}\text { Organic matter } \\
\text { assimilation }\end{array}$ & $\begin{array}{l}\text { Perennial } \\
\text { vegetation }\end{array}$ & $\begin{array}{l}\text { Presence of } \\
\text { native fauna }\end{array}$ & $\begin{array}{c}\text { Total evidence } \\
\text { rating } \\
\end{array}$ \\
\hline Anderson et al. 2003 [28] & 4 & 3 & 2 & N/A & 3 & N/A & 12 \\
\hline Borgmann et al.[29] & 1 & 1 & 3 & N/A & 3 & 3 & 11 \\
\hline Chambers and Lesh[29] & N/A & N/A & N/A & N/A & 3 & 3 & 7 \\
\hline Godwin 2004 [30] & $\mathrm{N} / \mathrm{A}$ & N/A & $\mathrm{N} / \mathrm{A}$ & N/A & 3 & N/A & 3 \\
\hline Hammersmark et al. 2009 [31] & $3^{*}$ & N/A & $3^{*}$ & N/A & 4 & N/A & 10 \\
\hline Herbst and Kane 2009 [32] & 3 & 3 & N/A & $\mathrm{N} / \mathrm{A}$ & 3 & 3 & 12 \\
\hline Holmquist et al. 2010 [33] & $\mathrm{N} / \mathrm{A}$ & N/A & $\mathrm{N} / \mathrm{A}$ & $\mathrm{N} / \mathrm{A}$ & 3 & 3 & 6 \\
\hline Key and Gish 1989 [34] & 3 & 2 & 2 & N/A & 3 & 2 & 12 \\
\hline Long and Endfield 2000 [35] & 2 & 2 & 2 & $\mathrm{~N} / \mathrm{A}$ & 2 & 1 & 9 \\
\hline Long et al. 2004a [36] & 1 & 1 & 1 & $\mathrm{~N} / \mathrm{A}$ & 1 & 1 & 5 \\
\hline Long et al. 2004b [37] & 4 & 3 & 2 & N/A & 3 & 3 & 15 \\
\hline Medina and Long 2004 [38] & 3 & 3 & 2 & $\mathrm{~N} / \mathrm{A}$ & 3 & 2 & 13 \\
\hline Medina and Steed 2002 [39] & 3 & 3 & 2 & N/A & 3 & 3 & 14 \\
\hline Norman and Immeker 2009 [40] & 4 & 4 & 4 & $\mathrm{~N} / \mathrm{A}$ & 3 & N/A & 15 \\
\hline Plumas Corporation 2004 [41] & 3 & 2 & 2 & N/A & 2 & N/A & 9 \\
\hline Plumas Corporation 2011 [42] & 3 & 2 & N/A & $\mathrm{N} / \mathrm{A}$ & 2 & 3 & 10 \\
\hline Ramstead 2011 [23] & 1 & 3 & $\mathrm{~N} / \mathrm{A}$ & 4 & 4 & N/A & 12 \\
\hline Rosen et al. 1999 [43] & 3 & 3 & 3 & N/A & 1 & N/A & 10 \\
\hline $\begin{array}{l}\text { Sierra Valley Resource } \\
\text { Conservation District } 2004 \text { [44] }\end{array}$ & 2 & 2 & 2 & N/A & 1 & 3 & 10 \\
\hline State of California 2005 [45] & 1 & 1 & 1 & $\mathrm{~N} / \mathrm{A}$ & 2 & 4 & 9 \\
\hline Swanson et al. 1988 [46] & 3 & 3 & 1 & $\mathrm{~N} / \mathrm{A}$ & 2 & 2 & 11 \\
\hline Szewczak 2004 [47] & $\mathrm{N} / \mathrm{A}$ & N/A & N/A & N/A & N/A & 3 & 3 \\
\hline Vrooman 2004 [48] & 3 & 3 & N/A & N/A & 3 & N/A & 9 \\
\hline Vrooman 2005 [49] & 3 & 2 & 1 & $\mathrm{~N} / \mathrm{A}$ & 3 & N/A & 9 \\
\hline Wilcox 2010 [50] & 4 & 4 & N/A & $\mathrm{N} / \mathrm{A}$ & $\mathrm{N} / \mathrm{A}$ & $\mathrm{N} / \mathrm{A}$ & 8 \\
\hline Wildlife Fish Habitat Initiative 2008 [29] & 2 & 3 & 2 & $\mathrm{~N} / \mathrm{A}$ & 3 & 3 & 13 \\
\hline Wolf and Cooper 2011 [25] & $3^{* *}$ & $3^{* *}$ & 4 & 1 & 3 & N/A & 14 \\
\hline Average Rating & 2.7 & 2.5 & 2.2 & 2.5 & 2.6 & 2.6 & 10.0 \\
\hline
\end{tabular}

*These are addressed more completely in a related study.

**The desired floodplain morphology in this case was a stable floodplain surface without a defined stream channel.

The six characteristics assessed are described in Table 1 and the rating system is described in Table 2.

effectively demonstrate that the post-project stream or floodplain configuration was similar to specified construction targets or to reference sites in relatively undisturbed meadows e.g., [25].

Probably the most important question regarding the effectiveness of geomorphological restoration techniques is how well they work in the long-term. Because most of the articles and project reports we reviewed covered no more than five years of post-project results, considerable caution is warranted. The wet meadows of the region contain many examples of failed efforts to restore stream channels [52, personal observations], most of which are believed to have failed during extreme flooding events. During the relatively short post-project periods covered by most of the articles and project reports included in this review, there were several examples of flood-related damage $[25,35,53,54]$. We have personally observed post-project damage at some sites that has not yet been reported in print, such as headcuts that have developed at the Hoxworth Springs restoration site [30] and failed log structures and gabions at Buck Springs Meadow and Merritt Springs Meadow [23] and elsewhere on the Coconino National Forest in northern Arizona.

While even seemingly well-designed projects have been damaged or failed completely, there is also encouraging evidence that others have been able to withstand truly extreme events. The best example of this may be the large flooding event withstood by a pond-and-plug project in 2009. The flood, which was determined to be in the 500-year return interval category, impacted the 
Big Meadows project [50]. Virtually no changes in channel morphology or to the plugs were observed despite the flashy nature of this flood and the fact that it occurred at a time of year (October) when the area was dry and the plugs and channel may have been most vulnerable to damage.

\section{Hydrology}

The efforts to restore geomorphic processes described in the previous section are primarily designed to return streamflow, overbank flooding, ground water levels and other aspects of a site's hydrology back to close approximations of their former patterns. The best evidence of success in achieving hydrologic restoration comes from direct measurements of these variables pre- and postproject, through the use of stream gauges, groundwater monitoring wells and similar techniques. Relatively few of the articles we reviewed used one or more of these techniques or monitored for sufficient periods of time to demonstrate substantial, long-term improvements in hydrology. Another challenge we faced was that, in some cases where it appears that adequate hydrological data were collected, the documents we reviewed did not present the data in detail.

Most of the highest quality data we could find on hydrology came from pond-and-plug projects in California, as well as the channel elimination project. One example is the first-ever pond-and-plug project in California, at Big Flat Meadow [29]. Monitoring of this project included stream gauges above and below the project site and a network of ground water monitoring wells along transects perpendicular to the stream. Interpretation of the data is somewhat confounded by the wide year-toyear variation in precipitation, but the data appear adequate to demonstrate that flow duration increased, peak flows below the project site decreased, groundwater levels increased, and stream temperature decreased as a result of the project, all of which are positive results.

A clearer and more dramatic effect on groundwater levels was reported for the Upper Halstead Meadow project. This project sought to eliminate (fill in completely) a gully and to restore a nearly level topography and a sheet flow hydrologic regime to the meadow [25]. Monitoring wells in this meadow showed wide variations in groundwater levels prior to restoration, with levels commonly dipping below $1.5 \mathrm{~m}$ during the growing season. Groundwater levels post-restoration fluctuated very little and remained within $20 \mathrm{~cm}$ of the surface for most of the three growing seasons that were monitored. Postproject groundwater levels were very similar to those recorded at five reference sites.

While other articles or project reports presented evidence of improvements in hydrology, most tended to do so with less data and sometimes relied on a combination of quantitative and qualitative evidence. An example is Medina and Long [38], whose primary treatment was the installation of riffle structures within a small creek channel. They reported that the riffles reduced the average distance from the streambed to the bank from 63 $\mathrm{cm}$ to $45 \mathrm{~cm}$. This in turn reduced the channel capacity and promoted overbank flooding, while also creating a streambank environment more conducive to the establishment of sedges. Accompanying pre- and post-project photos, showing the development of lush vegetation, provided supporting evidence of the project's success in restoring both geomorphology and hydrology.

Several efforts have been made to examine the effects of restoration projects on hydrology using numerical models [11,31,55-57]. These models have been developed and/or tested using data from project sites, and are promising tools for improving both our understanding of the effects of restoration and our ability to design better projects in the future. In one such modeling study, Hammersmark et al. [56] documented three types of hydrological responses to a pond-and-plug project, including (1) increased groundwater levels and subsurface storage, (2) increased frequency and duration of floodplain inundation, and (3) decreased annual runoff (by 1$2 \%$ ) and duration of base flow (by 2 weeks). The decreased runoff and duration of base flow was driven by the raised channel bed and higher evapotranspiration rates. In the simulations, additional water exited the site as groundwater flow as opposed to stream flow.

\section{Soils}

Other than the earthmoving associated with geomorphic restoration, we found little evidence of any direct manipulation of soils as part of restoration projects. Only in the case of small-scale research projects e.g., [26,27] did we encounter the use of soil treatments such as fertilization or aeration. Overall, little work appears to have been done on the effects of restoration on soil; most of what has been done focuses primarily on the effects of eliminating or reducing grazing.

Grazing clearly has caused considerable damage to wet meadows in the region and elsewhere in the western U.S. [58]. Therefore studies aimed at both quantifying the impacts of grazing and understanding how soils recover once it is reduced or eliminated can be very useful. Examples of studies that have quantified impacts of grazing are those of Flenniken et al. [59], Wheeler [60], and Blank et al. [61]. Flenniken et al. [59] demonstrated that grazing, even the very short-term grazing they examined, can significantly decrease microchannel sinuosity and drainage density, thereby increasing flow depths, total runoff and the potential for erosion. Wheeler [60] showed that short-term but moderately heavy grazing caused significant impacts to soil physical 
properties, but recovery was rapid once grazing was eliminated. Blank et al. [61] demonstrated grazing effects on soil nutrients, many of which increased in response to grazing. While potentially important, we did not attempt to include all the articles of this type on grazing effects, since they are only indirectly related to the central questions addressed in this review.

Studies such as [23,33] were designed to address more directly the effects of reducing or eliminating grazing on wet meadow soils, since protection from overgrazing is one of the most common restoration measures taken in the region. Holmquist et al. [33] found no differences in soil compaction between sites subject to light grazing by pack animals and ungrazed sites. Ramstead [23] examined two areas that had been subject to heavier grazing and found that approximately 20 years of protection from grazing resulted in generally less compacted soils and greater organic matter content.

A final type of study of relevance to soils and wet meadow restoration is more purely ecological in nature. Studies of this type are designed to help determine the relationship between site characteristics, including soils, and the occurrence of plant species and/or community types. Examples of such studies in the American Southwest include those by Benedict, Castelli et al. and Long et al. $[2,9,62]$. While these studies do not address the effects of restoration projects directly, they have the potential to be very useful for the design of future projects.

\section{Vegetation}

Of the 38 articles or reports that addressed vegetation in some way, 25 focused directly on operational-scale projects. Similar to what we have reported above, the type and quality of the data collected, as well as the length of post-project monitoring data collection, is highly variable. The evidence suggests, however, that generally good revegetation success can be obtained if the hydrology has been restored, the site is protected sufficiently from grazing and, where applicable, proper revegetation practices were used.

Wolf and Cooper [25] presented some of the most detailed information we found for an operational-scale project. Their results indicated good short-term survival ( $~ 97 \%)$ of the 34,250 seedlings that were initially planted at the site. Multivariate analyses showed a clear trend in the overall plant community towards dominance by wetter-site species and towards a greater resemblance to reference sites. Their results or observations also demonstrated some of the problems that can be encountered, however, including a substantial loss of planted seedlings following a large flooding/erosional event and slow growth of seedlings planted in the filled gully, where the fill had been excessively compacted. Both of these issues have reportedly been addressed successfully by refilling the damaged areas with a lighter mix that consisted of $70 \%$ soil and $30 \%$ sawdust.

When combined with data collected in the field, the modeling studies described above also provide good quality evidence of changes in vegetation caused by restoration projects. Hammersmark et al. [31], for example, used data from 170 vegetation plots established post-project, combined with their hydrologic model, to demonstrate that the habitat suitability for wetland plant species increased throughout a large portion of the project site.

Some of the evidence from restoration projects is qualitative but nonetheless compelling, including observations by experienced personnel and photo points that depict the same sites pre- and post-project. Good examples of photo point evidence can be seen for the Red Clover/McReynolds Creek [42]; Photos 2 and 3] and Pacheta Creek projects [38]; Figures 1 and 5), both of which show impressive development of wet meadow vegetation in the post-project photos.

In cases where the physical site conditions are suitable and grazing has been eliminated or reduced, active revegetation practices (e.g., transplanting of plugs or seeding) may not be required. Ammon and Stacey [6], for example, found that long-term ( $\sim 30$ year) protection of a riparian meadow from grazing resulted in a substantial recovery of willows (Salix spp.) and greater vertical vegetational diversity as opposed to a portion of the same meadow that is still subject to grazing. No other restoration practices other than exclusion of livestock grazing were reported for this meadow. Similar results were reported by Shulz and Leininger [5] who noted that, after 29 years of rest from grazing, the riparian vegetation was so dense that it concealed the stream from view. In their review papers, both and Platts and Rinne [63] and Elmore and Kaufmann [64] stated that protection of riparian sites from grazing has repeatedly been shown to result in the recovery of vegetation in western U.S. Wet meadows appear to be no exception.

Where they have been used, the results obtained using active revegetation practices have been mixed. The successes and problems encountered with planted seedlings in one project have already been mentioned above [25]. In a project that involved both substantial earth-moving and active revegetation [28] all project goals were reportedly met except for those associated with revegetation. While the approximately $1 / 3$ of the project area located furthest downstream was beginning to show successful Nebraska sedge (Carex nebrascensis) and Baltic rush (Juncus balticus) establishment, there was still an overall average of $64 \%$ bare ground 3 years post- restoration.

Restorationists could benefit from a number of studies that have been conducted in the region that focus either on plant species propagation or species-site relationships, several of which we have included in this review. Steed et al. [65] and Steed and DeWald [66], for 
example, provide practical information on three common Carex species based on their research on the species' responses to differing water table levels and transplanting methods. Articles such as those already mentioned in the soils section provide information on species-site relationships that can be used to guide species selection or to establish targets for restoring hydrology.

\section{Wildlife/biodiversity}

The response of wildlife and biodiversity to wet meadow restoration efforts has been investigated both directly, through changes in species presence and/or abundance, and indirectly, through changes in habitat characteristics. While generally positive effects have been noted, in some cases the data are confounded in ways that limit the ability to draw clear conclusions and in other situations the effects may be at least partially detrimental.

Studies that reported clear increases in animal species presence and/or abundance following restoration have been published for benthic macroinvertebrates [64], avifauna [42] and bats [47].

Changes in habitat quality have been reported for taxa as diverse as birds, small mammals, and fish. Ammon and Stacey [6] investigated the effects of protection of a wet meadow site from grazing on nest predation. The recovery of willows provided better cover, resulting in substantial declines in nest predation for both ground and aboveground nesting birds. The biggest impact was on ground nests, which had an $83 \%$ success rate on the restored site and only $36 \%$ in the portion of the same meadow that was still subject to grazing. Chambers and Lesh [unpublished manuscript[29]] found that Mogollon voles (Microtus mogollonensis) were captured more frequently and runway densities were higher inside exclosures located within several wet meadows in northern Arizona. Other articles have reported positive effects of restoration on habitat quality for trout, such as decreased water temperature $[13,42]$ and improved channel bed characteristics [36].

An example of a study with confounding effects is the Clarks Creek Project [45]. Increases in small mammals and avifauna were noted at the site after project implementation, but similar increases were noted at a nearby control site. Also, a decrease in the number of fish in the restored channel was observed post-project, but the decrease appears to have been caused by beaver dams that reduced access to the channel, rather than a decline in habitat quality of the restored reach. Borgmann et al. [67] reported confounding effects on butterflies, which increased in richness and abundance at the project site the year after implementation but also increased at nearby control sites. Confounding effects were also reported for another project in the Sierra Nevada region, in this case due to the difficulty of separating changes in bird captures at the restoration site from similar changes noted at a much larger network of capture sites in the area [44].

Potential negative impacts were noted for at least one pond-and-plug project, where two non-native species had become established in some of the ponds [44]. The two species (green sunfish; Lepomis cyanellus and bullfrog: Rana catesbeiana) are both known to prey on native fish and amphibians. Although no specific detrimental impacts were reported, this may be one aspect of the pond-andplug approach that would benefit from additional research. Permanent ponds are not a natural feature of most wet meadows and their presence may alter animal species communities in unintended ways.

\section{Reasons for variation in effectiveness}

We cannot pinpoint any instances where there was variation in the effectiveness of projects that were truly comparable in terms of ecological setting, disturbance history, and treatments applied. In reality each project was unique. The fact that each meadow and stream complex is unique - and therefore requires site-specific treatments - was mentioned by several of the restoration practitioners and researchers that we contacted during the course of this review.

In a more general sense, however, there are many factors that can be identified that cause variation in project effectiveness. In the Upper Halstead Meadow Project, for example, the initial effectiveness of the project was reduced by the choice of fill material and by compacting the material excessively. This resulted in both increased susceptibility to erosion and to reduced growth of seedlings planted in the fill material [25]. It is clear from the literature on restoration of other types of ecosystems that variations in project design, quality of construction, choice of planting material, level of training and supervision of the personnel implementing the project, and many other variables associated with project implementation can have a large effect on the results e.g., [68].

In addition to factors related to project design and implementation, year-to-year variation in environmental conditions such as precipitation, temperature, timing of snowmelt, and flooding can also have a large impact on projects. The two main effects of this type of variation are damage to projects caused by major events such as large storms/floods e.g., $[25,50,54,69]$ and difficulties in interpreting research or monitoring results caused by more typical variation among years in water table levels or other environmental conditions [26,27].

\section{Review limitations}

Key limitations of this review include (1) the scarcity of studies that were designed to address our specific questions in a rigorous, quantitative fashion, (2) the 
inaccessibility of data (versus general descriptions of the results) for most of the projects that included monitoring components, (3) wide variation in methods of data collection, analysis and presentation, which effectively ruled out a meta-analysis, (4) year-to-year environmental variation that confounded the results in some cases, and (5) the relatively short duration of post-project data collection for most of the studies we found.

Another critical concern is that many restoration projects appear to have been implemented over the years, going back at least to the 1930's [50], yet little or no information is available on many (and probably a majority) of them. Our review would have been stronger if the effectiveness of more wet meadow projects had been investigated over the years or, in cases where they were investigated, if the results had been made more widely available. Although speculative, we suspect that the results of projects that failed are less likely to have been published, and yet much can be learned from failed projects. Also, if most failed projects were not reported in accessible formats, then our results may be biased by a tendency to report more frequently on successful projects. None of the articles we found reported a total failure to achieve the stated objectives, although one reported on damage that may have resulted in failure if it hadn't been effectively repaired [25].

A broader search strategy may have yielded additional articles that would have been useful to us. In particular, a search strategy that encompassed more completely the literature on grazing management in riparian areas e.g., [64] and the restoration of riparian habitat for fisheries e.g., [63] may have been valuable in the context of this review. We also recognize that important work has been done on wet meadow restoration in other regions, much of which could be relevant to restoration efforts in the American Southwest.

\section{Reviewers' conclusions}

While much of the evidence is not of the highest quality and therefore considerable caution is warranted, it is nevertheless apparent that progress has been made over the past 20 years in wet meadow restoration. In particular, especially important contributions have been made in restoring the highly degraded wet meadow systems that are characterized by deep, wide and relatively straight gullies. There is substantial evidence that the pond-and-plug approach, which was first implemented approximately 15 years ago, is an effective technique for restoring most aspects of these systems, albeit at the cost of creating new features (ponds) that are not necessarily natural features of wet meadows.

Important lessons continue to be learned about wet meadow restoration practices, including those aimed at establishing suitable floodplain and stream channel morphology, a more natural hydrologic regime, and more effective revegetation. The damage that continues to plague many projects, such as erosion and structure damage caused by floods, demonstrates that we still have much to learn about project design and implementation. It also suggests we have to recognize that post-project vigilance and a commitment to ongoing maintenance will be needed to ensure long-term success.

\section{Implications for management}

One of the most important implications for managers is that not enough information on the projects carried out to date has been documented and shared. During the course of this review, we encountered several projects in the field or on websites for which no substantive documentation of any kind could be located; we expect that this is common throughout the region. Many opportunities to learn both from successes and failures have undoubtedly been lost over the years due to this failure to document projects and to make the information widely available. Making more project information available through websites can be a powerful tool. The Feather River Coordinated Resource Management group's website (http://www.feather-river-crm.org/) is perhaps the best example in the region of this approach to sharing information on wet meadow restoration.

We understand that there are serious constraints on managers' time and resources, but allocating additional effort to project documentation, including more formal and longerlasting monitoring programs, is an important need that should be addressed. One approach that might help in this regard is for practitioners to work with scientists from government agencies, local universities and colleges, and other organizations. When this type of collaboration has happened in the past it appears to have been effective e.g., [47].

\section{Implications for research}

More research on wet meadow ecosystem processes, the ecology of individual plant and animal species, and specific restoration and management techniques clearly would be beneficial. We have developed a list of research questions that would be worthwhile to address. While many of these have been investigated to some degree already, there is much more to learn. Although they are listed within each section in order of priority from our perspective, we realize that research priorities may vary depending on the predominant types of disturbance being addressed within a given area, as well as the management priorities of government agencies and other landowners.

\section{Geomorphology and Hydrology}

- How do the pond-and-plug technique, rechannelization, and smaller-scale channel restoration 
techniques perform in the long-term, especially in terms of stream channel/floodplain stability?

- How can we improve upon current practices to make them more resistant or resilient to disturbances such as flooding?

- It would be valuable to investigate the impact and development of created ponds (when using the pondand-plug technique) more than has been done to date - what impact do they have on meadow hydrology and do they show signs of filling in over time?

- How do individual restoration projects affect water storage, streamflow and water supplies downstream? What is the cumulative effect of a large number of projects on the water budget in a watershed?

- How might climate change impact hydrology and the likelihood of extreme events? Should we be planning for such changes in the design of wet meadow restoration projects?

\section{Soils}

- How do soils at restoration sites of different ages compare to relatively undisturbed meadows?

- When are soil treatments needed during project implementation to increase survival and growth of vegetation? What treatments are most effective?

\section{Vegetation}

- When can we rely on natural revegetation and when do we need to use techniques such as planting or seeding?

- What improvements do we need to make to wet meadow plant species propagation and establishment techniques?

\section{Wildlife/Biodiversity}

- What is the impact of the pond-and-plug approach (and the ponds in particular) on wildlife? Do the ponds harbor species that otherwise would not occur in wet meadows? If so, what are their impacts?

- What is the impact of restoration practices on individual species that have endangered, threatened, or sensitive status (e.g., Apache trout, mountain yellow-legged frog?

\section{Other}

- Would improved wet meadow classification systems help guide restoration project design?

- Are there viable alternatives to fencing that require less maintenance?

- What types of livestock grazing regimes are compatible with wet meadow restoration?
- Many wet meadows are on tribal lands. What is the cultural importance of wet meadows to various tribes? What can we learn from the way they managed wet meadows in the past?

- What is the true scope of the need for wet meadow restoration? How many degraded or destroyed meadows are there, where are they, and how many are realistic candidates for restoration?

\section{Additional files}

Additional file 1: Appendix A. Summary of included articles [70-75]

Additional file 2: Appendix B. Summary of database search results.

Additional file 3: Provided with this submission: Articles excluded at full text assessment.

\section{Competing interests}

The Ecological Restoration Institute (ERI) of Northern Arizona University provided financial and editorial support for this project. The reviewers are not aware of any conflicts of interest that might result from this support.

\section{Authors' contributions}

KR conducted all of the literature searches, except those done after 2009 using Google Scholar. She also conducted the title, abstract, and full text filtering (the latter in cooperation with JA) and wrote the first draft of the manuscript. JA initiated this review, designed the protocol, conducted the Google Scholar searches, and provided extensive assistance with the analysis and writing. AS provided input into the protocol and reviewed earlier drafts of the manuscript. All authors read and approved the final manuscript.

\begin{abstract}
Acknowledgements
We would first like to thank the Ecological Restoration Institute of Northern Arizona University for funding this project. Dick Fleishman of the United States Forest Service, Coconino National Forest helped keep us inspired by taking us on several field trips of local wet meadow restoration projects. The feedback from Jonathan Long of the Pacific Southwest Research Station has been invaluable. Jonathon also helped us get in contact with several other people involved in wet meadow restoration. We would like to thank all the practitioners and researchers who participated in a survey that was helpful in looking at the different benefits and disadvantages of individual restoration techniques. Some of them also provided us with literature for this review. Finally, we would like to thank Liz Kalies, of the Ecological Restoration Institute, as well as two anonymous reviewers and the Environmental Evidence editorial staff, for their guidance and comments on earlier drafts of this review.
\end{abstract}

\section{Author details}

${ }^{1}$ School of Forestry, Northern Arizona University, P.O. Box 15018, Flagstaff, AZ 86011, USA. ${ }^{2}$ School of Earth Sciences and Environmental Sustainability, Northern Arizona University, P.O. Box 4099, Flagstaff, AZ86011, USA.

Received: 11 January 2012 Accepted: 25 August 2012

Published: 14 September 2012

\section{References}

1. Patton DR, Judd Bl: The role of wet meadows as wildlife habitat in the Southwest. J Range Manage 1970, 23:272-275.

2. Benedict NB: Plant associations of subalpine meadows, Sequoia National Park, California. Arctic Alpine Res 1983, 15:383-396.

3. Hendrickson DA, Minckley WL: Ciénegas - vanishing climax communities of the American Southwest. Desert Plants 1984, 6:131-175.

4. Muldavin E, Durkin P, Bradley M, Stuever M, Mehlhop M: Handbook of wetland vegetation communities of New Mexico, Volume l: Classification and community descriptions. Albuquerque, NM, USA: New Mexico Natural Heritage Program, Biology Department, University of New Mexico; 2000. 
5. Schulz TA, Leininger WC: Differences in riparian vegetation structure between grazed areas and exclosures. J Range Manage 1990, 43:295-299.

6. Ammon EM, Stacey PB: Avian nest success in relation to past grazing regimes in a montane riparian system. Condor 1997, 99:7-13.

7. Long JW: Evaluating recovery of riparian wetlands on the White Mountain Apache Reservation. In Ph.D. dissertation. Northern Arizona: Northern Arizona University, School of Forestry; 2002.

8. Judd Bl: Vegetation zones around a small pond in the White Mountains of Arizona. Great Basin Nat 1972, 32:91-96.

9. Castelli RM, Chambers JC, Tausch RJ: Soil-plant relations along a soil-water gradient in Great Basin riparian meadows. Wetlands 2000, 20:51-266.

10. Dwire KA, Kauffman JB, Baham JE: Plant species distribution in relation to water-table depth and soil redox potential in montane riparian meadows. Wetlands 2006, 26:31-146.

11. Loheide SP, Deitchman RS, Cooper DJ, Wolf EC, Hammersmark CT, Lundquist JD: A framework for understanding the hydroecology of impacted wet meadows in the Sierra Nevada and Cascade Ranges, California, USA. Hydrogeol I 2009, 17:229-246.

12. Dahl TE: Wetlands losses in the United States, 1780's to 1980's. Washington, D. C.: U.S. Department of the Interior, Fish and Wildlife Service; 1990.

13. National Fish and Wildlife Foundation: Business Plan: Sierra Nevada Meadow Restoration. Washington, D.C.: National Fish and Wildlife Foundation; 2010. http://www.nfwf.org/Content/ContentFolders/

NationalFishandWildlifeFoundation/GrantPrograms/Keystones/ WildlifeandHabitat/Sierra_Meadow_Restoration_business_plan.pdf

14. Dodd NL, Gagnon JW, Boe S, Schweinsburg RE: Assessment of elk highway permeability by using global positioning system telemetry. J Wildlife Manage 2007, 71:1107-1117.

15. Arizona Game and Fish Department: Apache Trout abstract compiled and edited by the Heritage Data Management System. Phoenix, Arizona: Arizona Game and Fish Department; 2001. http://www.azgfd.gov/w_c/edits/ documents/Oncoapac.fo_000.pdf.

16. Medina AL: Native aquatic plants and ecological condition of southwestern wetlands and riparian areas. Albuquerque, New Mexico: USDA Forest Service, Rocky Mountain Forest and Range Experiment Station, General Technical Report RM-GTR-272; 1996:329-335.

17. Richardson DM, Holmes PM, Eisler KJ, Galatowitsch SM, Stromberg JC, Kirkman SP, Pysek P, Hobbs RJ: Riparian vegetation: Degradation, alien plant invasions, and restoration prospects. Divers Distrib 2007, 13:126-139.

18. Chambers JC, Miller JR (Eds): Geomorphology, hydrology, and ecology of Great Basin meadow complexes - implications for management and restoration. USDA Forest Service General Technical Report RMRS-GTR-258. Fort Collins, Colorado: Rocky Mountain Research Station; 2011.

19. Neary DG, Medina AL: Geomorphic response of a montane riparian habitat to interaction of ungulates, vegetation, and hydrology. In Desired Future Conditions for Southwestern Riparian Ecosystems: Bringing Interests and Concerns Together, USDA Forest Service General Technical Report RM-GTR272. Edited by Shaw DW, Finch DM. Fort Collins, Colorado: Rocky Mountain Forest and Range Experiment Station; 1996:143-147.

20. Gage E, Cooper DJ: Historic range of variation assessment for wetland and riparian ecosystems, US Forest Service Region 2. Golden, Colorado: USDA Forest Service, Region 2; 2008.

21. Allen-Diaz BH: Water table and plant species relationships in Sierra Nevada meadows. Am Midl Nat 1991, 126:30-43.

22. Brown DE: Biotic communities of the Southwestern United States and Northwestern Mexico. Salt Lake City: University of Utah Press; 1994.

23. Ramstead KM: Wet meadow restoration in the Southwestern United States. In MSc thesis. Northern Arizona: Northern Arizona University, School of Forestry; 2011

24. Pullin AS, Knight TM: Support for decision making in conservation practice: An evidence-based approach. J Nat Conserv 2003, 11:83-90.

25. Wolf E, Cooper D: Restoration of Geomorphic Structure, Hydrologic Regime, and Vegetation in Upper Halstead Meadow: Colorado State University, Fort Collins, CO; 2011. http://www.cfc.umt.edu/CESU/NEWCESU/Assets/Individual \%20Project\%20Reports/NPS\%20Projects/CSU/2005/ 0506 08Cooper SEKI Halstead\%20Meadow frpt.pdf.

26. Martin DW, Chambers JC: Effects of water table, clipping, and species interactions on Carex nebrascensis and Poa pratensis in riparian meadows. Wetlands 2001, 21:422-430.

27. Martin DW, Chambers JC: Restoring degraded riparian meadows: biomass and species responses. J Range Mgmt 2001, 54:284-291.
28. Anderson D, Springer AE, Kennedy J, Odem W, DeWald L, Fleishman D: Verde River Headwaters Restoration Demonstration Project, Final Report. Arizona: Water Protection Fund, Grant No. 98-059; 2003.

29. Wild Fish Habitat Initiative: Big Flat Meadow Re-Watering Project. Bozeman, MT: Montana Water Center, University of Montana-Bozeman; 2007. http:// wildfish.montana.edu/Cases/browse_details.asp?Project|D=43.

30. Godwin TN: Evaluation of streambed restoration and occurrence of Hoxworth Springs, Coconino County, Arizona. In MSc thesis. Northern Arizona: Northern Arizona University, Geology Department; 2004.

31. Hammersmark CT, Rains MC, Wickland AC, Mount JF: Vegetation and water-table relationships in a hydrologically restored riparian meadow. Wetlands 2009, 29:785-797.

32. Herbst DB, Kane JM: Responses of aquatic macroinvertebrates to stream channel reconstruction in a degraded rangeland creek in the Sierra Nevada. Ecol Restor 2009, 27:76-88.

33. Holmquist JC, Schmidt-Gengenbach J, Haultain SA: Does long-term grazing by pack stock in subalpine wet meadows result in lasting effects on arthropod assemblages? Wetlands 2010, 30:252-262.

34. Key JW, Gish MA: Clark Canyon (Mono County) riparian demonstration area. In In Proceedings the California Riparian Systems Conference, September 22-24, 1998, Davis, California; USDA Forest Service General Technical Report PSW-110. Albany, CA: USDA Forest Service, Pacific Southwest Research Station; 1988:127-134

35. Long JW, Endfield D: Restoration of White Springs, Proceedings of Land Stewardship in the $21^{\text {st }}$ Century: The contributions of watershed management. U.S.D.A. Forest Service Proceedings RMRS-P-13. Fort Collins, Colorado, USA: Rocky Mountain Research Station; 2000:358.

36. Long JW, Burnette BM, Medina AL, Parker JL: Restoration of Soldier Spring: an isolated habitat for native Apache trout, Proceedings of the $16^{\text {th }}$ International Conference, Society for Ecological Restoration, August 24-26, 2004. Victoria, Canada: 2004.

37. Long JW, Burnette BM, Medina AL: Restoring wetlands after the RodeoChediski wildfire, Proceedings of the $16^{\text {th }}$ International Conference, Society for Ecological Restoration, August 24-26, 2004. Victoria, Canada: 2004.

38. Medina AL, Long JW: Placing formations to restore stream functions in a wet meadow. Ecol Restor 2004, 22:120-125.

39. Medina AL, Steed JE: West Fork Allotment riparian monitoring study 1993-1999. Fort Collins, CO: USDA Forest Service, Rocky Mountain Research StationFinal Project Report Volume I; 2002

40. Norman S, Immeker D: Interim Monitoring Report for the Big Meadow Creek in Cookhouse Meadow Restoration Project. South Lake Tahoe, CA: USDA Forest Service, Lake Tahoe Basin Management Unit; 2009. http://www.fs. usda.gov/Internet/FSE_DOCUMENTS/stelprdb5158607.pdf.

41. Plumas River Corporation: Last Chance Watershed Restoration Project CalFed Agreement \#2000-E01 Final Report. 2004. http://www.feather-river-crm.org/ images/pdfs/calfed_final.pdf.

42. Plumas Corporation: Red Clover/McReynolds Creek Restoration Project Monitoring Report. 2010. http://feather-river-crm.org/pdf/ RedCloverMonitoringRpt2010.pdf.

43. Rosen J, Jemison R, Pawelek D, Neary D: Using GIS technology to analyze and understand wet meadow ecosystems. In USDA Forest Service Proceedings RMRS-P-7. Fort Collins, CO: Rocky Mountain Research Station; 1999:175-199.

44. Sierra Valley Resource Conservation District: Carman Valley Watershed Restoration Project, Final Report. 2004. http://www.feather-river-crm.org/pdf/ CarmanFinalReport\%2011_2004.pdf.

45. State of California: Clarks Creek Stream/Meadow Restoration Project Fish and Wildlife Monitoring Report: District Report. 2004. http://www.feather-river-crm. org/images/pdfs/clarks_report.pdf.

46. Swanson S, Franzen D, Manning M: Rodero Creek: Rising water on the high desert. J Soil Water Conserv 1987, 42:405-407.

47. Szewczak JM: Bats of Carman Valley, Report 1997-2004 Survey and Monitoring. Quincy, CA: Feather River Coordinated Resource Management, Plumas Corporation; 2004. http://www.feather-river-crm.org/pdf/ CarmanBatReport2004.pdf.

48. Vrooman S: Comanche Creek Morphology and Riparian Vegetation Monitoring Report; 2005. http://comanchecreek.org/images/links/30Morphology_and_Riparian_Monitoring_Report_2005.pdf.

49. Vrooman S: Cedro Creek Monitoring Report Final Report, 2005-2007; 2008. http://quiviracoalition.org/images/global/52Pedro_Creek_2008_Monitoring_Report.pdf. 
50. Wilcox J: Big Meadows Restoration Project, October 14, 2009 Flood Event. Technical Report \#1, Plumas Corporation; 2010. http://www.feather-river-rm. org/pdf/BigMeadowsTechReport.pdf.

51. Lindquist DS, Wilcox J: New concepts for wet meadow restoration in the Northern Sierra Nevada, Proceedings of the International Erosion Control Association, Conference 31. California: Palm Springs; 2000:145-152.

52. Wilcox J, Benoit T, Mink L: Evaluation of geomorphic restoration techniques applied to fluvial systems. Quincy, CA: Feather River Coordinated Resource Management Group; 2001. http://www.feather-river-crm.org/project-files/ georest/cover.html.

53. Jemison $\mathrm{R}$ : Forest road reengineering to restore riparian meadow conditions in the Zuni Mountains of New Mexico, Proceedings of the 2003 Internationa Conference on Ecology and Transportation. Raleigh, NC, USA: Center for Transportation and the Environment, North Carolina State University; 2003:99-106.

54. Quivira Coalition: Comanche Creek Watershed Restoration Project-Restoring Habitat for the Rio Grande Cutthroat Trout, Part 2 EPA 319(h) Final Report. Santa FE, NM: Quivira Coalition; 2008. http://comanchecreek.org/images/ links/206-Comanche_II_Final_Report_9-19-08.pdf.

55. Loheide SP, Gorelick SM: Riparian hydroecology: a coupled model of the observed interactions between groundwater flow and meadow vegetation patterning. Water Resour Res 2007, 43:W07414. 16 pp.

56. Hammersmark CT, Rains MC, Mount JF: Quantifying the hydrological effects of stream restoration in a montane meadow, northern California, USA. River Res Appl 2008, 24:735-753.

57. Hammersmark CT, Dobrowski SZ, Rains MC, Mount JC: Simulated effects of stream restoration on the distribution of wet-meadow vegetation. Restor Ecol 2010, 18:882-893.

58. Kaufmann JB, Krueger WC: Livestock impacts on riparian ecosystems and streamside management implications: a review. J Range Mgmt 1984 37:430-438

59. Flenniken M, McEldowney RR, Leininger WC, Frasier GW, Trlica MJ: Hydrologic responses of a montane riparian ecosystem following cattle use. J Range Mgmt 2001, 54:567-574.

60. Wheeler MA, Trlica MJ, Frasier GW, Reeder JD: Seasonal grazing affects soil physical properties of a montane riparian community. J Range Manage 2002, 55:49-56.

61. Blank RR, Svejcar T, Riegel G: Soil attributes in a Sierra Nevada riparian meadow as influenced by grazing. Rangeland Ecol Manage 2006, 59:321-329.

62. Long JW, Tecle A, Burnette BM: Geologic influences on recovery of riparian wetlands on the White Mountain Apache Reservation. J ArizonaNevada Acad Sci 2003, 36:46-60.

63. Platts WS, Rinne JN: Riparian and stream enhancement management and research in the Rocky Mountains. N Am J Fish Manage 1985, 5:115-125.

64. Elmore W, Kaufmann B: Riparian and watershed systems: degradation and restoration. In Ecological Implications of Herbivory in the West. Edited by Vavra M, Laycock WA, Pieper RD.; 2004:212-231.

65. Steed JE, DeWald LE, Kolb TE: Physiological and growth responses of riparian sedge transplants to groundwater depth. Int J Plant Sci 2002, 163:925-936.

66. Steed JE, DeWald LE: Transplanting sedges (Carex spp.) in Southwestern riparian meadows. Restor Ecol 2003, 11:247-256.

67. Borgmann KL, Groce J, Morrison ML: Chapter Il: Cookhouse Meadow Restoration Project. South Lake Tahoe, CA: USDA Forest Service, Lake Tahoe Basin Management Unit; 2007. http://www.fs.usda.gov/Internet/ FSE_DOCUMENTS/stelprdb5150406.pdf.

68. Kusler JA, Kentula ME: Wetland Creation and Restoration: Status of the Science. Washington, D.C: Island Press; 1990.

69. Jemison $\mathrm{R}$ : Forest road reengineering to restore riparian meadow conditions in the Zuni Mountains of New Mexico. In Proceedings of the 2003 International Conference on Ecology and Transportation. Edited by Irwin Cl, Garrett P, McDermott KP. Raleigh, North Carolina: Center for Transportation and the Environments, North Carolina State University; 2003:99-106.

70. Beck JL, Peek JM: Herbage productivity and ungulate use of northeastern Nevada mountain meadows. J Range Manage 2004, 57:376-383.

71. Mount JF, Hammersmark CT: Ecohydrologic effects of stream restoration. In UC Water Resources Center Technical Completion Report Project No. WR-995. Berkeley, CA: University of California; 2007:46.
72. Jones KL, Roundy BA, Shaw NL, Taylor JR: Environmental effects on germination of Carex utriculata and Carex nebrascensis relative to riparian restoration. Wetlands 2004, 24:467-479.

73. Mullen RM, Springer AE, Kolb TE: Complex effects of prescribed fire on restoring the soil water content in a high-elevation riparian meadow, Arizona. Restor Ecol 2006, 14:242-250.

74. Norton JB, Bowannie F Jr, Peynetsa P, Quandelacy W, Siebert SF: Native American methods for conservation and restoration of semiarid ephemeral streams. J Soil Water Conserv 2002, 57:250-258.

75. Sarr DA, Dudley TL: Survival and restoration potential of beaked sedge (Carex utriculata) in grazed riparian meadows of the southern Sierra Nevada (California). Ecol Restor 2008, 26:186-188.

doi:10.1186/2047-2382-1-11

Cite this article as: Ramstead et al:: Have wet meadow restoration projects in the Southwestern U.S. been effective in restoring geomorphology, hydrology, soils, and plant species composition? Environmental Evidence 2012 1:11.

\section{Submit your next manuscript to BioMed Central and take full advantage of:}

- Convenient online submission

- Thorough peer review

- No space constraints or color figure charges

- Immediate publication on acceptance

- Inclusion in PubMed, CAS, Scopus and Google Scholar

- Research which is freely available for redistribution 